\title{
Priority-partnership approach as a mechanism for encouraging investment activities at the railway transport
}

\author{
Oleg Vasyliev ${ }^{1}$,Volodymyr Volokhov ${ }^{1}$, Inna Volokhova ${ }^{11}$, Olena Lukianova ${ }^{1}$, and \\ Hanna Zhovtiak ${ }^{2}$ \\ ${ }^{1}$ Ukrainian State University of Railway Transport, Kharkiv, Ukraine \\ ${ }^{2}$ O. M. Beketov National University of Urban Economy in Kharkiv, Kharkiv, Ukraine
}

\begin{abstract}
Modern economic conditions and the integration of the national economy into the global economy require structural changes and a search for a new model of relationship between the public and private sectors. The relevance of this article is determined by the fact that the existing scientific concepts have not formed a general understanding of the theoretical aspects for the implementation of public-private partnership at the railway transport, have not established development priorities and tasks of the state in the implementation of the mechanism of public-private partnership at the railway transport. Realization of the projects capable of maintaining implementation of the development priorities of the railway industry requires significant investments of private business and financial, organizational and legal support of the state. The authors substantiate the necessity of using public-private partnership at the railway transport of Ukraine for solving the most urgent current problem - renewal of the material and technical resources and bringing them in line with the requirements of the leading European countries. The proposed prioritypartnership approach and the obtained results open up new opportunities for further research into the solution of the problem regarding the implementation of public-private partnership at the railway transport.
\end{abstract}

\section{Introduction}

One of the most pressing problems in the development of Ukrainian railways is bringing their material and technical resources in line with the technical, economic, social and environmental requirements of economically developed countries. However, the limited own resources of the railways and the low investment capacity of the state constrain the implementation of such large-scale projects. According to foreign experience, one of the most effective tools for the development of the transport infrastructure is the mechanism of public-private partnership (PPP).

The authors share V.P. Gudkova's point of view that the railway transport of Ukraine is experiencing hard times when the deterioration of the financial state of railways, the lack

\footnotetext{
${ }^{1}$ Corresponding author: innavolokhova76@gmail.com
} 
of budget funding for the implementation of infrastructure projects and the full-value compensation of reduced-fare passenger transportation by the state lead to the impossibility of its self-financing and maintaining innovation and technological branch transformations $[2]$.

\section{Problem Statement}

The key problem that endangers the implementation of PPP projects is the low investment opportunities of the state and significant constraints of the financial resources of the railway industry. Taking into account the current state of the transport infrastructure objects (at the beginning of 2015, wear of rolling stock was 99\% [2]), emergency conditions of the railway tracks, the steady and successful development of the railway transport can hardly be expected. All this requires intensification of investment activity and attraction of private capital in the implementation of socially significant infrastructure projects. The works by the leading scientists (V.Varnavsky, V. Tsvetkov, A. Medkov) are devoted to the conceptual foundations of public-private partnership [3-6]. Y. Sich, Yu. Vdovenko, I. Zapatrina dealt with the implementation of PPP projects in the transport complex [7-9]. The problem of cooperation between the state and business at the railway transport remains insufficiently studied and requires additional research, especially, in the conditions of limited budget receipts for the development of the railway industry and the existence of crisis phenomena in the economy.

\section{Research Questions}

The main issues of this research are as follows:

- further study of the theoretical aspects of the implementation of public-private partnership at the railway transport;

- identification of development priorities and state tasks in designing a mechanism for public-private partnership at the railway transport.

\section{Purpose of the Study}

The purpose of the study is to substantiate the need for the application of public-private partnership at the Ukrainian railway transport with the aim of increasing the investment attractiveness of the railway industry under further reform.

\section{Research Methods}

In studying the theoretical and methodological foundations of public-private partnership, the authors used the dialectic method of cognition for the formation of prerequisites for the development of public-private partnership and the possibility of its introduction at the railway transport; principles of system analysis $\neg$ to identify the priority conditions for the operation of economic entities in the railway transportation system; methods of statistical processing and data analysis - to estimate the costs of economic entities; fundamental provisions of the economic theory $\neg$ to clarify the meaning of the notion "public-private partnership", the substantiation for the notion "mechanism of public-private partnership"; the laws of social development - to substantiate the prerequisites for the implementation of public-private partnership projects; systematic approach - to analyze the processes of interaction between the state and private business in a market-transforming economy and to substantiate the priority-partnership approach for the implementation of the mechanism of 
public-private partnership at the railway transport; structural-functional analysis $\neg$ to research the structural-functional relations in the system of railway transportation.

\section{Findings}

The problem of government financing for construction and maintenance of socially significant infrastructure projects in modern Ukraine is quite acute. Budgetary funds are usually not sufficient for such infrastructure objects, but the private business has a required level of funds. On the one hand, enterprises of infrastructure industries, in the first place their monopoly segments, cannot be privatized due to the strategic, economic and sociopolitical significance of infrastructure objects, but, on the other hand, there are not enough funds in the state budget to provide such enterprises with reproduction processes. Just for the solution of the issue regarding direct private investment in social infrastructure objects, the state's efforts in public-private partnership projects are concentrated.

The problems facing modern society cannot be solved without a partnership between the authorities and business. The authorities can no longer cope with complex problems that arise in the field of economy, social maintenance, ecological environment, urban development, etc., neither financially nor methodologically or organizationally. Business, implementing strategic infrastructure projects, is not capable of overcoming extremely high risks existing in the relevant fields without the corresponding liabilities of the authorities regarding the consistency of legal regulation.

The situation is complicated by the fact that the state and society are generally distrustful and very cautious about the private sector.

The matter in hand is mainly due to the negative experience regarding the management of state and communal property by private operators. But there is also some fault of the state that has created unfavourable conditions for private business, which, along with political instability and corruption, repel private partners. Under such conditions, it is impossible to rely on the development of public-private partnership in Ukraine without stimulating these processes by the state. Budgetary support and administration of state guarantees are one of the most widely used opportunities for such stimulation worldwide [9].

Public-Private Partnership (PPP) is an alternative to the privatization of vitally important, strategically significant state-owned objects. According to a contemporary view, PPP is an institutional and organizational alliance between the state and business that pursues the goal of the implementation of national and international, large-scale and local, but always socially significant projects in a wide range of fields: from the development of strategically important industries, research and development activities to providing public services [10].

As stated in the National Transport Strategy of Ukraine for the period up to 2030 [11], most of the investment funds for improving the infrastructure are expected from external sources, primarily from international financial institutions, private investors and publicprivate partnership projects.

Within this framework it becomes necessary to define more exactly the priorities of the development of the railway system and the state's tasks in the field of transport development. The solution of the problems regarding the improvement of efficiency, complex renewal and modernization of the railway transport of Ukraine may be carried out by the system methods, combining the complex of normative legal support of its activities with the creation of a favourable investment climate, by consolidation of budgetary and non-budgetary sources of investment with the aim of completing a number of transport structural reforms. 
According to the authors, the implementation of the mechanism of public-private partnership makes most sense to be applied taking into account the priorities that belong to the state or private sector.

The notion "public-private partnership" or "private-public partnership" should be used depending on who will have a key role in management, responsibility and risk-taking. Thus, according to the Rules of registration and maintenance of private freight cars, the infrastructure of railway transport is considered to be a technological complex that consists of public railway tracks, railway stations, power supply devices, communication networks, signals and interlocking systems, information systems and train control systems, and buildings, structures, devices and equipment maintaining the operation of this complex [12]. In this instance, the state should reserve a key role in preserving the state form of property for infrastructure objects and in controlling the safety performance with the aim to maintain the unified technological process, the integrity of the property complex and the strategic importance of the railway industry. Attraction of private investments in a monopoly sector is possible, provided that it will not hinder efficient operation of the railway complex. For the development of infrastructure projects, private investments will work only in that case when private companies begin to receive their dividends. Under the restriction of state financial resources, the development of railway infrastructure, according to the authors, can be ensured on the basis of public-private partnership.

The potentially competitive sector at the railway transport is represented by the freight and passenger transportation, repair of rolling stock, etc.

Railway freight transportation is profitable; therefore, in this field the free competition among operator companies for freight transportation should develop. Besides, for the transportation of strategic goods, for the retention of the key role in maintaining the defence potential of the state, it is necessary to create the National Freight Transportation Operator. Along with the National Operator there will be private operators in the freight market that have to compete with each other.

Passenger transportation is socially significant because it performs the transportation of low-income social groups. At the initial stage, the mechanism of private-public partnership in the passenger transportation sector can be the most efficient because the private sector will have a key role and the state will support the attraction of private capital by means of the development of appropriate mechanisms for supporting private investors, assumption of risks and liability, and exercise of influence at the legislative level. Further development of private-public partnership has to be aimed at the transition to the free competition in the field of passenger transportation.

This approach is essentially a priority-partnership one. The substantiation of the priority partnership approach is presented in Fig. 1. The subject of cooperation between the public and private structures will become the modernization of the railway infrastructure and the development of internal industry competition, and the entities of cooperation will be railway enterprises, private investors and the state. The parties of the public-private partnership should respond in proper time to the increase in demand for public services and meet public needs for quality services. The parties also attract additional financial resources for technical development (modernization) of the infrastructure, rendering of services and may allocate funds of the state and local budgets for the implementation of social and economic programmes. Due to the introduction of public-private partnership, the expansion of the competitive sector takes place and, consequently, there is a choice of an optimal private partner.

Therefore, the mechanism of partnership will stimulate the efficiency increase of railway companies, the quality improvement of transportation due to the competition in the market of transport services, and, based on it, the competitiveness increase of the railway industry. 


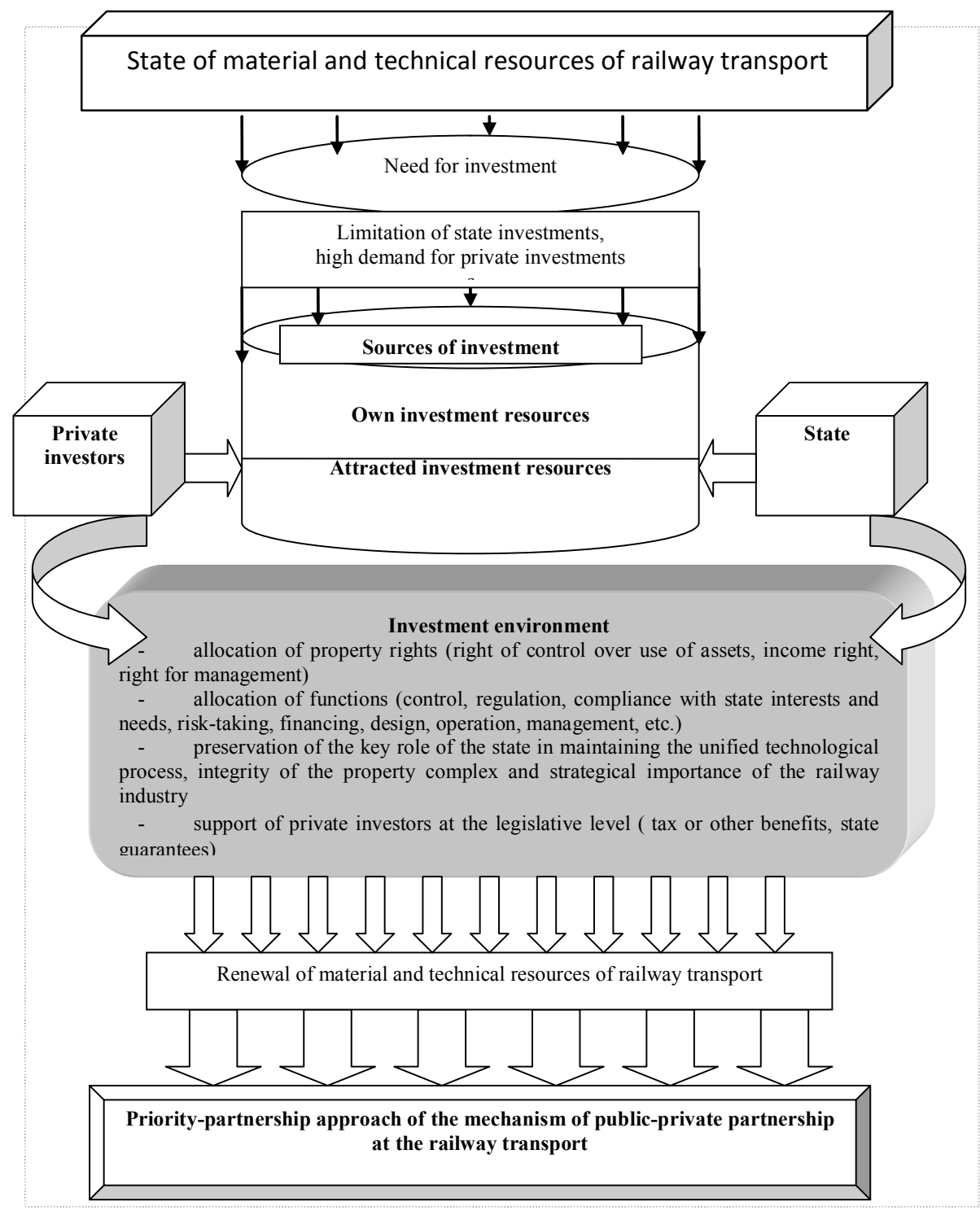

Fig. 1. Substantiation of priority-partnership approach

\section{Conclusion}

The proposed priority-partnership approach has to be a step forward towards further structural changes in the railway branch. The attraction of private investments will create opportunities for additional revenues for renewal and modernization of the material and technical resources of the railway transport and will promote the competitiveness of transport services.

\section{References}

1. V. Kruhlov, Publichne administruvannia: teoriia ta praktyka [Public administration: Theory and practice], Dnipro, 2 (2013) 
2. V.P. Hudkova, O.V. Yarmolitska, Ekonomichnyi forum [Economic forum], 1, 129-137 (2016)

3. V. Varnavsky, Otechestvennye zapiski [Domestic proceedings], 6(21) (2004)

4. V.G. Varnavsky, Kontsessionny mechanizm partnerstva gosudarstva $i$ chastnogo sektora [Concession mechanism of partnership between state and private sector] (MONO: IMEMO RAN, Moscow, 2003)

5. V.G. Varnavsky, Partnyorstvo gosudarstva $i$ chastnogo sektora: teoria i praktika [Public-private partnership: theory and practice] (Nauka, Moscow, 2005)

6. V.A. Tsvetkov, A.A. Medkov, Zhurnal ekonomicheskoi teorii [Russian Journal of Economic Theory], 1, 170-182 (2008)

7. E.M. Sych, Y.S. Vdovenko, Zbirnyk naukovykh prats KUETT [Collection of Scientific Papers of KUETT], 9, 198-202 (2007)

8. Y.S. Vdovenko, Pryvatno-derzhavne partnerstvo v avtodorozhnii sferi [Private-public partnership in the road sector] (ChDTU, Chernihiv, 2009)

9. I.V. Zapatrina, Ekonomika i prohnozuvannia [Economy and forecasting], 4, 62-86 (2010)

10. Public-Private Partnerships in Infrastructure Days: Edited by Periklis Saragiotis. PPP Program, World Bank Institute, Day 2, Washington (2008)

11. Pro skhvalennia Natsionalnoi transportnoi stratehii Ukrainy na period do 2030 roku [On the Approval of the National Transport Strategy of Ukraine for the period up to 2030], Kyiv (2018)

12. Pravyla reiestratsii ta ekspluatatsii vlasnykh vantazhnykh vahoniv, zatverdzheni Ministerstvom transportu ta zviazku Ukrainy 28.09.2004 r. No.856 [Rules for registration and operation of private freight wagons], Ukrzaliznytsya, Kyiv (2004) 